\title{
TLR-dependent human mucosal epithelial cell responses to microbial pathogens
}

\author{
Ryan McClure ${ }^{1}$ and Paola Massari ${ }^{2 *}$ \\ ' Department of Microbiology, Boston University School of Medicine, Boston, MA, USA \\ 2 Section of Infectious Diseases, Department of Medicine, Boston University School of Medicine, Boston, MA, USA
}

\section{Edited by:}

Abhay Satoskar, The Ohio State

University, USA

\section{Reviewed by:}

Xun Suo, China Agricultural

University, China

Olivier Dussurget, University Paris

Diderot, France

\section{*Correspondence}

Paola Massari, Section of Infectious

Diseases, Department of Medicine,

Boston University School of

Medicine, EBRC, 650 Albany Street,

Room 635, Boston, MA 02118, USA

e-mail:pmassari@bu.edu
Toll-like receptor (TLR) signaling represents one of the best studied pathways to implement defense mechanisms against invading microbes in human being as well as in animals. TLRs respond to specific microbial ligands and to danger signals produced by the host during infection, and initiate downstream cascades that activate both innate and adaptive immunity. TLRs are expressed by professional immune cells and by the large majority of non-hematopoietic cells, including epithelial cells. In epithelial tissues, TLR functions are particularly important because these sites are constantly exposed to microorganisms, due to their location at the host interface with the environment. While at these sites specific defense mechanisms and inflammatory responses are initiated via TLR signaling against pathogens, suppression or lack of TLR activation is also observed in response to the commensal microbiota. The mechanisms by which TLR signaling is regulated in mucosal epithelial cells include differential expression and levels of TLRs (and their signaling partners), their cellular localization and positioning within the tissue in a fashion that favors responses to pathogens while dampening responses to commensals and maintaining tissue homeostasis in physiologic conditions. In this review, the expression and activation of TLRs in mucosal epithelial cells of several sites of the human body are examined. Specifically, the oral cavity, the ear canal and eye, the airways, the gut, and the reproductive tract are discussed, along with how site-specific host defense mechanisms are implemented via TLR signaling.

Keywords: epithelial cells, mucosal tissues, pattern recognition receptors, immunity, bacteria

\section{INTRODUCTION}

All organisms have some form of protective mechanisms against pathogens. In many instances, innate immunity functions are the first, and sometimes, the only barrier to infection by invading organisms. In human beings, innate immunity is not only mediated by professional immune cells, but also by non-professional cell types that contribute to defense responses by secreting substances with anti-microbial activity and inflammatory mediators that favor rapid and direct involvement of professional immune cells. Many, if not all, of these responses are dependent on detection of invading microorganisms. The toll-like receptors (TLRs) family is one of the best characterized among several cellular effectors for pathogen detection (1). TLRs are a family of trans-membrane proteins widely expressed by eukaryotic cells and recognize ligands that are present in virtually all types of microorganisms. Once binding takes place, activation of signaling pathways downstream of TLRs plays a major role in directing both innate and adaptive host immune responses. Thus, TLRs represent one of the first and most important lines of defense against bacterial, viral and fungal pathogens and parasites that may interact with and harm the human host. However, two major aspects relative to TLR-dependent pathogen recognition and subsequent responses need to be carefully considered: most microorganisms that colonize the human host are not pathogens, and, depending on the site of colonization/infection, different defense responses may be necessary or appropriate to counteract such infections. This review explores how TLR signaling is regulated in mucosal epithelial cells to mediate specific host responses to commensal or pathogenic microbial infections. Such control is exerted via a number of mechanisms, including regulation of receptor expression levels, cellular localization (i.e. cytosolic or surface expression) and positioning within the tissue (apical or basolateral expression), and also depending on the tissue body site.

\section{TOLL-LIKE RECEPTORS: OVERVIEW OF STRUCTURE ANID SIGNALING PATHWAYS}

Toll-like receptors were discovered almost two decades ago and their importance in regulation of immune responses was immediately recognized, enhancing our understanding of many phenomena that define host innate and adaptive immunity. TLRs recognize microbial and viral products with specific structural features. Such products are classified as pathogen-associated molecular patterns (PAMPs) (2). As many microorganisms colonize the human host without causing disease, the term CAMPs has been introduced for commensal-associated molecular patterns (or the more generic term MAMPs, for microbial-associated molecular patterns) that are also recognized by TLRs (3). In addition, endogenous ligands that induce inflammation in the absence of infection can also activate TLR-dependent signaling and are defined as danger-associated molecular patterns (DAMPs) (4). 
Toll-like receptors are trans-membrane proteins that contain a horseshoe-shaped extracellular or cytoplasmic leucine-rich repeat (LRR) domain and an intra-cytoplasmic toll/IL-1R (TIR) domain [homologous to the corresponding intracellular domain of the IL-1 receptor (IL-1R)], which are connected by a single transmembrane domain. The LRR domain is responsible for ligand recognition and the TIR domain for intracellular signal transfer.

In humans 10 TLRs have been identified to date and comprise both extracellular and intracellular receptors (1). TLR1, TLR2, TLR4, TLR5, TLR6, and TLR10 are surface-expressed and recognize extracellular microorganisms and ligands. TLR3, TLR7, TLR8, and TLR9 are intracellular, localizing into cytosolic endosomal compartments via a UNC-93B-assisted translocation mechanism (5), and are engaged by microorganisms and ligands that have already crossed the cell membrane barrier. In some instances, intracellular TLRs, such as TLR3 and TLR9, can be expressed on the cell surface, and extracellular TLRs, such as TLR4, can also have an intracellular localization, depending on the cell type $(6,7)$. For all TLRs, ligand binding to the LRR domain induces formation of receptor homodimers or, in some cases, heterodimers (Figure 1). A resulting TIR domain conformational change allows interactions between TIR domains of adjacent TLRs and binding of additional adaptor proteins essential for triggering intracellular signaling cascades. Adaptor proteins identified to date include the myeloid differentiation factor 88 (MyD88) (8), the MyD88 adaptor-like (Mal) (9) [also called TIR domain-containing adaptor protein, TIRAP (10)], the TIR domain-containing adaptor protein inducing interferon- $\beta$ (TRIF) (11) [also called TIR-containing adaptor molecule, TICAM (12)], and the TRIF-related adaptor molecule (TRAM) (13). TLR signaling is also subject to negative regulation by a variety of inhibitory factors, including the Toll-interacting protein (Tollip), IRAK-M, the sterile $\alpha$ - and HEAT-Armadillomotif-containing protein (SARM), and the B cell adaptor for PI3K (BCAP) (14), which inhibit downstream steps in the TLRdependent signaling cascades. The crystal structure of several TLRs has been solved, either alone or in complex with ligands (15-19), expanding our understanding of the molecular mechanisms of TLR activation and of the co-factors that are required for signaling.

With the exception of TLR3, all TLRs require MyD88 recruitment to the TIR domain. TLR2 and TLR4 signaling require not only MyD88 but also the cooperation of Mal/TIRAP (Figure 1). Through MyD88, members of the IL-1R-associated protein kinases (IRAKs) IRAK4, IRAK1, and IRAK2 are activated (20). This is directly followed by activation of the tumor necrosis factor receptor-associated factor 6 (TRAF6) (21) and RIP (22), which proceed to activate a complex made of TGF- $\beta$-activated kinase 1 (TAK1) and TAK1-binding proteins (TAB1, TAB2, and TAB3). Lastly, gene expression regulatory factors of the MAPK family (ERK, JNK, p38) and NF- $\kappa$ B are activated (Figure 1), inducing cell survival and proliferation, immune cell activation, production of pro-/anti-inflammatory mediators (cytokines and chemokines), interferons, and anti-microbial products. Activation of intracellular TLR7, TLR8, and TLR9 also proceeds via MyD88, but can trigger TRAF6, IRAK4, and TRAF3-dependent activation of IRF7, which translocates to the nucleus and induces production of type-I interferon $(13,23)$ (Figure 1).

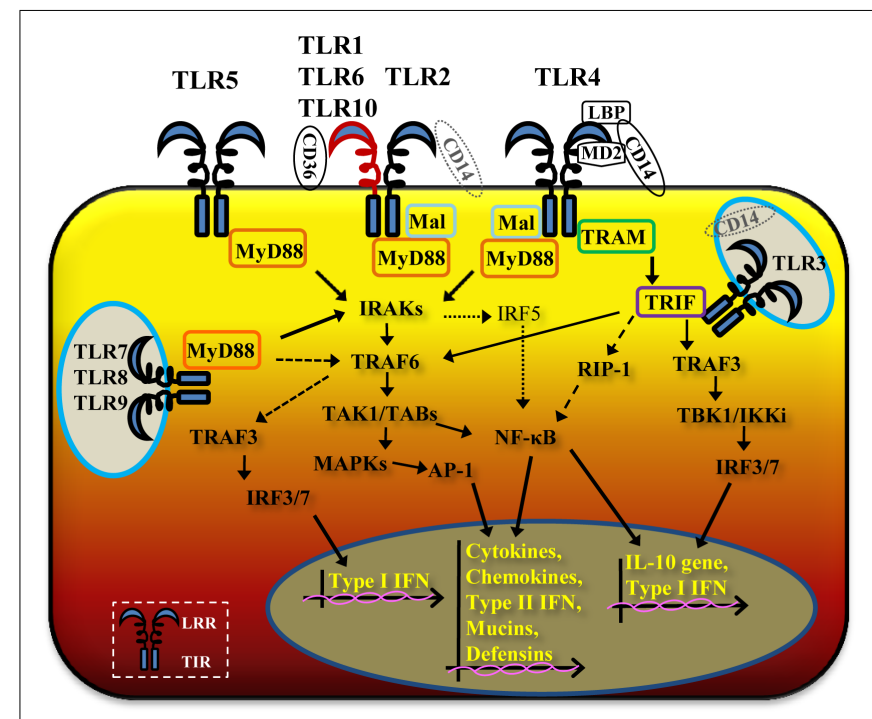

FIGURE 1 | Schematic cartoon of TLR signaling pathways. TLR2/TLR1 and TLR2/TLR6 heterodimers and TLR4 and TLR5 homodimers are located on the cell surface, while TLR3, TLR7, TLR8 and TLR9 homodimers have an intracellular localization. Occasionally, in specific epithelial cell types and tissues, TLR4 can be expressed intracellularly or TLR3 and TLR9 on the cell surface. Ligand binding to the leucine-rich repeat (LRR) domain of TLR dimers brings the TIR domains of adjacent TLRs in proximity, allowing multiple signaling pathways via different adaptor molecules. TLR2/TLR1 and TLR3 potentially cooperate with CD14, TLR2/TLR6 with CD36 and TLR4 requires LBP, CD14 and MD-2. TLR1, TLR2, TLR4, TLR5, TLR6, TLR7, TLR8 and TLR9 activate the MyD88-dependent pathway, with cooperation of Mal for TLR2 and TLR4. Through MyD88, IRAKs and TRAF6, TLR2/TLR1 and TLR2/TLR6, TLR4, TLR5, TLR7, TLR8, and TLR9 signaling pathways lead to activation of NF-кB and MAPKs, with production of inflammatory cytokines and chemokines, type-II interferon, mucins, and defensins (solid thick arrows). TLR7, TLR8, and TLR9 also induce MyD88-dependent activation of TRAF6 and TRAF3 (dashed arrows). TLR3 and TLR4 activate a

MyD88-independent pathway via TRIF and, in cooperation with TRAM for TLR4 (solid medium arrows), also leading to NF-KB and MAPKs activation and of inflammatory mediators, type-Il interferon, mucins, and defensins. The MyD88-independent pathway also induces IRF3 and IRF7 activation, with production of type-I IFNs and IL-10 gene activation.

A MyD88-independent pathway is triggered by TLR3 and TLR4 (in addition to the TLR4/MyD88-dependent signaling pathway) and, potentially, by TLR2 $(24,25)$. The TLR3 MyD88-independent pathway is mediated by TRIF and the TNF receptor associated factor protein TRAF3, inducing non-canonical IKKs, TBK1, and IKK $\varepsilon$ pathways, activation of IRF3, and secretion of type-I IFN (IFN$\beta$ ) and IL-10 (26) (Figure 1). TLR3-TRIF signaling can also drive activation of MyD88-dependent downstream components TRAF6 and RIP1, thus converging on activation of NF- $\kappa \mathrm{B}$ (Figure 1). The TLR4/MyD88-independent pathway leads to recruitment of TRIF via activation of TRAM and downstream segregation of cell activation via both TRAF6/RIP1 and TRAF3/IRF3 pathways (27) (Figure 1).

\section{TLR LIGANDS: OVERVIEW OF INTERACTIONS}

Toll-like receptors recognize a large variety of structurally defined, but not necessarily structurally related ligands. TLR3, TLR5, TLR7, 
TLR8, and TLR9 recognize "unique type" of ligands. TLR3 recognizes viral double-strand RNA (dsRNA) and synthetic analogs of dsRNA, such as Poly I:C (28), with the potential contribution of the adaptor molecule CD14 (29). Bacterial flagellin is the ligand for TLR5 (30), TLR7 and TLR8 recognize viral single-strand RNA, miRNA and the anti-viral compounds, imidazoquinolines (3134), and TLR9 recognizes unmethylated CpG DNA of bacterial and viral origin (35) as well as the malaria pigment, hemozoin [likely due to its being coated with malarial DNA (36)]. A unique ligand for TLR10 is currently unknown but this receptor is thought to heterodimerize with TLR2 and share recognition of ligands that are in common with those that are recognized by TLR1. Recently, a role for TLR10 has been suggested in responses to pathogen infections (37, 38), Crohn's disease (39), and even cancer (40).

Ligand discrimination by TLR 2 and TLR 4 is a complex process that is not only dependent on ligand compatibility but also requires the presence of specific co-receptors and accessory molecules. In the case of TLR4, recognition of its best characterized ligand, bacterial lipopolysaccharide (LPS) occurs when this is in complex with the accessory molecules lipid binding protein (LBP) and the lipid A binding protein (CD14), and is presented to TLR4 in the presence of the myeloid differentiation protein 2 (MD-2) (41). Homodimerization of the TLR4/MD-2 complex following ligand binding then brings the TLR4 TIR domains in close proximity, which proceeds to trigger signaling cascades via the MyD88-dependent or the MyD88-independent pathways (Figure 1). It has been suggested that this dichotomy may be influenced by the LPS type (smooth vs. rough or lipid A). In the presence of CD14, all LPS types can induce TLR4 activation via both pathways. In the absence of CD14, smooth LPS fails to induce TLR4 activation, while lipid A induces signaling via Mal/MyD88 (42). The details of the molecular interactions of TLR4 with its accessory molecules and ligands have been elucidated in elegant crystal structure studies (17). A novel factor involved in TLR4-mediated signaling has been described, the TLR4-interactor with LRRs, TRIL, which is highly expressed particularly in the brain and enhances TLR4-dependent signaling by LPS (43). Some types of bacterial LPS signal via TLR2, for example Porphyromonas gingivalis LPS, although some components of TLR4-dependent signaling are also involved (44). In addition to LPS, TLR4 also recognizes viral components and endogenous ligands, such as $\beta$-defensin 2 (45), high mobility group box 1 protein (HMGB1) (46), fibronectin extra domain A (F-EDA), heat shock proteins and other molecules (47), although the contribution of contaminating LPS to the effect of some of these molecules is still unclear.

An even more complex picture characterizes signaling via TLR2, which can form heterodimers with either TLR1 or TLR6. TLR2 recognizes a broad range of ligands with very different structural features. The first described TLR2 ligands are lipopeptides and lipoproteins, shown to engage TLR2/TLR1 or TLR2/TLR6 heterodimers depending on different acyl group patterns. The synthetic triacylated lipoprotein $\mathrm{Pam}_{3} \mathrm{CSK}_{4}$ is a specific ligand for the TLR2/TLR1 dimer (48) while the diacylated lipoprotein $\mathrm{Pam}_{2} \mathrm{CSK}_{4}$ binds to and signals via the TLR2/TLR6 dimer (but can also function via TLR2/TLR1) $(49,50)$. The molecular and structural details of the TLR2/TLR1- and TLR2/TLR6-ligand complexes have been elucidated by co-crystallization studies that have paved the way in defining these sophisticated interactions and the role of the accessory molecules CD14, LBP, and CD36 in liganddriven complex formation $(16,51,52)$. Other bacterial ligands for TLR2 include cell wall components such as lipoteichoic acid (LTA) (53), glycolipids, lipoarabinomannan (54), $\beta$-glucans (55) and zymosan (56). TLR2 activation by peptidoglycan (PG) is controversial and this molecule is also known to signal via another intracellular pattern recognition receptor, Nod2, a member of the nucleotide oligomerization domain (NOD)-like receptors (NLRs) family (57-59). In addition, bacterial proteins of diverse origin with no structural similarities and no lipid components have also been shown to activate cells via TLR2 signaling, for example porins and toxins. Porins from Neisseriae species, Fusobacterium nucleatum and Chlamydia induce TLR2/TLR1-dependent signaling (60-64), while Shigella and Salmonella porins induce signaling via TLR2/TLR6 $(65,66)$. Haemophilus porin is also considered a TLR2 ligand (67). Other well-described TLR2 protein ligands are the pentameric B subunit of the Escherichia coli type-II heat-labile enterotoxin [LT-IIa-B(5) and LT-IIb-B(5)] (68), bacterial fimbriae (69) and the PPE18 protein from Mycobacterium tuberculosis (70). Furthermore, endogenous ligands and DAMPs are also associated with TLR2-dependent signaling, including HSPs, HMGB1, uric acid, fibronectin and other extracellular matrix proteins, and some types of LPS, as discussed in the previous section.

\section{TLRS IN HUMAN EPITHELIAL CELLS: OVERVIEW OF EXPRESSION AND FUNCTIONS}

In humans TLR expression is nearly ubiquitous in immune cells, where it drives innate and adaptive immune mechanisms such as activation of antigen-presenting cells (APCs), secretion of inflammatory mediators, $\mathrm{T}$ cell differentiation and antibody production. By contrast, TLR expression is less widespread in cells of nonhematopoietic origin, such as epithelial cells (Table 1). Since TLRs are specialized in recognition of microbial products, it appears reasonable that they have evolved to be localized at the best potential host/microbe interface for a rapid initial response. For example, depending on the cell type and the body location, TLR protein expression may not be detected despite the presence of TLR mRNA, extracellular TLRs may present an intracellular localization in endosomal compartments (i.e., TLR4) while intracellular TLRs can be found on the cell surface (i.e., TLR3 or TLR9), and selected TLRs can be expressed in a tissue-specific manner. TLR-dependent activation of immune responses by a pathogen is indiscriminately triggered in APCs, but a similar modality of activation of epithelial cells may lead to unnecessary responses to the large number of commensal organisms found throughout the majority of non-sterile body surfaces that are in constant contact with the environment (Figure 2). The best and most studied examples include the selective expression of TLR 2 and TLR4 by cells of mucosal epithelial sites such as the oral cavity, the upper and lower airways (including the nasal passage), the ear and the eye, the gut and the reproductive tract, as well as the skin (even if the majority of the skin tissue comprises cells of non-mucosal nature). Although the first function of these cells is that of offering a mechanical barrier against pathogens, they also have an intimate relationship with both circulating and local immune cells [i.e., resident neutrophils, dendritic cells (DCs) and macrophages]. 
Table 1 |TLR mRNA and protein expression in mucosal epithelial cells.

Tissue
TLR

mRNA Protein

\section{ORAL EPITHELIA}

Gingival

Tonsillar

Ear epithelia

\section{OCULAR EPITHELIA}

Corneal

Conjunctival

Iris

\section{AIRWAY EPITHELIA}

Nasal

Tracheal/bronchial

Lung

\section{GUT EPITHELIA}

Esophageal

Gastric

Intestinal

$M$ cells/Paneth cells
TLR1 (71, 72), TLR2 (73-75), TLR3 (73), TLR4 (73, 75, 76), $\operatorname{TLR} 5$ (71, 72), TLR6 (71, 72), TLR7 (73), TLR8

(71-73), TLR9 $(71,72)$

TLR1-TLR10 $(80,81)$

TLR1-TLR6, TLR9, TLR10 $(80,82)$

TLR2-TLR4, TLR9 (83-86)
TLR1 (71), TLR2 (71-73, 75-78), TLR3 (71, 73, 78), TLR4 (71-76), TLR5 (71, 77, 78), TLR6 (71, 72, 78), TLR7 (71, 73), TLR8 (71), TLR9 (71, 74, 75, 79)

TLR1-TLR4, TLR7 (80)

TLR2, TLR3 (82)

TLR2-TLR4, TLR9 (83-86)
TLR1 (87), TLR2 (6, 87-90), TLR3 (87-89), TLR4 (6, 87-89), TLR5 (87, 91), TLR6 (87), TLR7 (87, 88), TLR9 (87-89), TLR10 (87)

TLR1 (87), TLR2, TLR3 (87, 88), TLR4 (87, 88, 99), TLR7 (87, 88), TLR9 $(87,88,99)$, TLR10 (87)

TLR1-TLR7, TLR9 (100)

TLR4 (98)
TLR1 (92), TLR2 (6, 87, 90, 92-96), TLR3 (6, 87-89, 92, 93), $\operatorname{TLR} 4$ (6, 88, 90, 93, 96-98), $\operatorname{TLR} 5$ (87, 91-95, 97), TLR6 (92), TLR9 $(87,89)$

TLR3 (88), TLR4 (88, 99), TLR9 (99)

TLR2-TLR4 (100)

TLR4 (98)

\section{TLR1-TLR10 (101, 102)}

$\operatorname{TLR} 1$ (7, 81, 104), $\operatorname{TLR} 2(7,81,104,105), \operatorname{TLR} 3(7,81$, 104), $\operatorname{TLR} 4$ (7, 81, 104, 106), TLR5-TLR10 (7, 81, 104)
TLR2 (102, 103), TLR3 (102), TLR4 (103)

TLR1, TLR2 (7, 104, 105, 107), TLR3 (7, 104, 107), TLR4 (7, 104, 106, 107), TLR5, TLR6 (7, 104, 107), TLR7, TLR9, TLR10 (7)

\section{GENITO-URINARY EPITHELIA}

Male

Penile, urethra testis, prostate

Female

Vagina

Endocervix/endocervix

Endometrium, uterus/fallopian tubes

Urinary tract/renal
TLR1, TLR2 (81), TLR3 (81, 125-127), TLR4-TLR7 (81), TLR8 (81, 125-127) TLR9, TLR10 (81)

TLR1-TLR6, TLR9, TLR10 (129, 130)

TLR1-TLR3, TLR5-TLR9 (130, 132)

TLR1-TLR6 (130), TLR7-TLR9 (130, 133, 134)

TLR1-TLR5, TLR9 $(135,136)$
TLR1-TLR3 (113), TLR4 (113, 114), TLR5 (113)

TLR2, TLR4, TLR5 (115-117)

TLR2 (81, 118, 119) TLR3 (123), TLR4 (118, 120-122), TLR5 (119, 123), TLR9 (123)

TLR2, TLR4, TLR5 (124)
TLR2 (81, 125-128), TLR3, TLR4 (128), TLR8 (125), TLR9 (81, 125-127) 


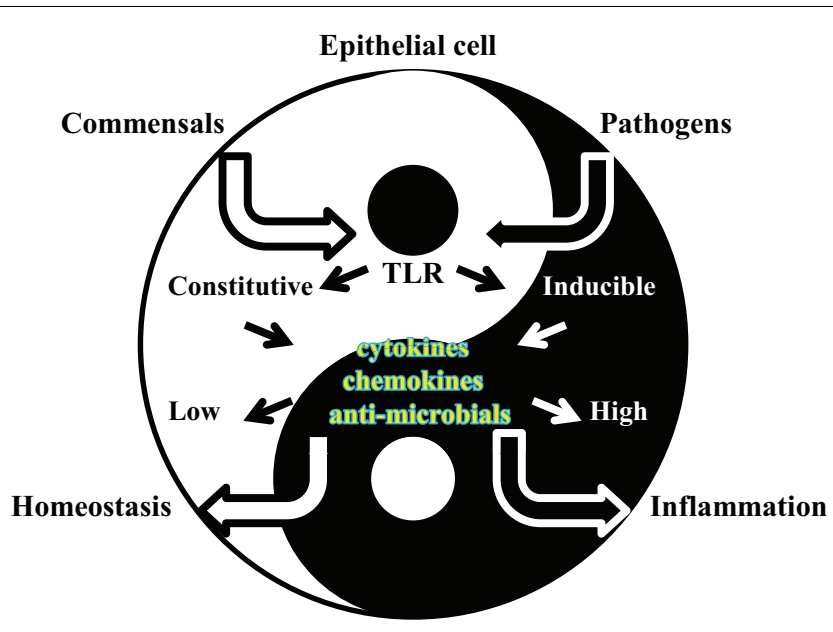

FIGURE 2 | Cartoon of epithelial cell/microorganisms dynamic interactions. Bacterial recognition by TLRs expressed by epithelial cells leads to activation of local defense responses in the epithelial tissues that become colonized. TLR-dependent induction of anti-microbial substances and inflammatory mediators contribute to bacterial clearance by controlling organism survival and by triggering host local and systemic immune responses, respectively. While such processes are pivotal against pathogens, they are not desirable against the local commensal microflora. In a Yin-Yang balance of epithelial tissue homeostasis and defense/inflammatory responses, regulation of TLR signaling is crucial for inducing appropriate cell responses to microorganisms of different nature.

Direct defense functions mediated by TLR signaling in mucosal epithelial tissues include induction of anti-microbial substances and other soluble mediators for local and systemic control of infections. Production of anti-microbial substances is beneficial for controlling mucosal epithelial tissue colonization/infection but production of inflammatory mediators is a double-edged sword. In fact, while pro-inflammatory cytokines trigger recruitment and activation of APCs at the site of infection, they may also favor inflammatory tissue damage. One example is the damaging effect of TNF- $\alpha$ on oral bone integrity. Following infection by oral pathogens such as $P$. gingivalis, gingival epithelial cells, and macrophages that are recruited to this site secrete high levels of TNF- $\alpha$, which then causes enhanced inflammatory oral bone loss. In addition, uncontrolled secretion of inflammatory cytokines is not desirable for maintaining local tissue homeostasis in the presence of the commensal microbiota. On the other hand, lack of inflammatory responses is similarly dangerous in the instances when pathogen infections or commensal imbalance may occur.

The inflammatory cytokines and chemokines most frequently produced by epithelial cells via TLR stimulation include those directly involved in inflammatory and immune regulation (i.e., IL$1 \alpha$ and IL- $1 \beta$, IL- 6 , IL-10, IL-13, TNF- $\alpha$, and TGF- $\beta$ ), those with chemotactic effects (such as IL-8, MCP-1, MIP-1, and RANTES) and growth and differentiation factors (i.e., IL-3, IL-7, G-CSF, and GM-CSF). The activity of some of these mediators encompasses several of the categories mentioned above. However, some promote inflammation and amplify immune responses, for example IL-1 $\beta$, IL-8, RANTES, or TNF- $\alpha$, while others dampen such responses, such as IL-10, IL-37, and TGF- $\beta$ (141). Besides secreting inflammatory mediators, epithelial cells influence mucosal innate and adaptive immunity by also producing factors that directly affect DC, B and T cell functions, such as the B cell-activating factor of the TNF family (BAFF), a proliferation-inducing ligand (APRIL) $(142,143)$ and type-I interferons.

\section{TLR EXPRESSION AND RESPONSES IN HUMAN MUCOSAL EPITHELIAL TISSUES \\ ORAL EPITHELIUM}

The gingival epithelium is composed of a variety of cell types including keratinized and non-keratinized, stratified and flat squamous cells, which are exposed to an enormous number of microorganisms of both commensal and pathogenic nature. It is thought that up to $10^{10}$ bacteria can be found in the oral cavity. In physiologic conditions, a relatively small number of resident immune cells, including neutrophils, lymphocytes and monocytes/macrophages, are located within the oral cavity epithelial tissue. Upon oral pathogen infection, TLR-dependent gingival inflammation causes an influx of neutrophils, monocytes and lymphocytes to facilitate bacterial clearance (144).

Toll-like receptor expression and functions in the oral cavity are very important for the maintenance of oral tissue homeostasis because of the constant presence of commensal microbes (Table 1). Expression of mRNA for TLR1 to TLR9 has been detected in oral epithelial cells (including the tongue), although actual TLR protein expression and cellular localization can be variable and inducible. TLR2 is highly expressed in cells of the gingival basal layer but lower levels are observed in cells of the superficial layers, more exposed to the environment and to microorganisms. While an opposite spatial relationship may be expected to insure recognition of colonizing microorganisms, this is a strategy that facilitates TLR-dependent inflammatory response only when invading pathogens are detected in the basal cell layer. A similar pattern is observed for TLR1, TLR3, TLR4, TLR5, and TLR9 expression, also depending on the state of the tissue (inflamed vs. non-inflamed) $(71,72)$. TLR7 and TLR8 expression is comparable in both healthy and infected tissues. In addition, acute and persistent gingival inflammation also enhances the expression of TLR2 and TLR4, favoring downstream local innate immune responses (73). In chronic oral inflammatory conditions (i.e. bacterial periodontitis or other pathologies), TLR4 expression in the gingival epithelium decreases, likely to dampen inflammatory responses that may exacerbate damage to oral tissue and bone (76). Variable levels of TLR expression have also been observed as a consequence of other oral chronic inflammatory conditions, for example caused by lichen planus. In this case, increased TLR4 and TLR9 protein expression and decreased TLR2 mRNA have been detected (74, 75). High constitutive expression of TLR1, TLR2, TLR3, TLR4, and TLR7 mRNA has also been shown in vitro in salivary gland epithelial cells, with TLR3 protein levels being the highest (80). mRNA for all TLRs except TLR7 and TLR8 has been observed in tonsillar epithelial cells at the junction between the oral cavity and the airways. A strong expression of TLR 2 and TLR3 mRNA is observed in both tonsillar cell lines and primary cells, and detection of actual TLR2 and TLR4 proteins and their activity appears variable (82). 
The likely most relevant defense mechanism that is mediated by TLR signaling in the oral cavity is induction of anti-microbial substances such as defensins ( $\alpha-, \beta$-, and $\theta$-type). Human $\beta$-defensin (hBD)-1 to hBD-4 mRNA and proteins are expressed in the oral epithelium (145). hBD-1 is constitutively expressed, hBD-2 and hBD-3 are inducible in the basal layer epithelial cells via TLR2, TLR3, TLR4, TLR5 and TLR9 signaling, and by general inflammatory conditions of the gingival epithelium (i.e., in the presence of IL- $1 \beta$ and TNF- $\alpha$ ). hBD- 4 is only induced by bacterial infections (146). In a feedback mechanism, $\beta$-defensins also induce TLR signaling and recruitment/activation of immature DCs, monocytes and memory $\mathrm{T}$ cells in the oral epithelium, which thus places these substances at a cross-road between an immune effector and an immune inducer produced by epithelial cells (147). Overall, activation of TLR2 signaling is generally more frequent than that of TLR4 in gingival epithelial cells, inducing a strong activation of MAPKs and NF- $\kappa$ B pathways than controls production of antibacterial substances (148).

Oral epithelial cells do not generally secrete high levels of inflammatory mediators, likely to avoid excessive local innate immune responses resulting in tissue destruction. Secretion of IL8 in response to TLR9, TLR2 and TLR 5 stimulation and, to a lesser extent, to TLR4 stimulation has been shown in gingival epithelial cells, which is enhanced by a prior cell exposure to IFN- $\gamma$ (77, $79,149)$. Besides IL-8, secretion of other inflammatory cytokines directly involved in innate immunity, such as IL- $1 \beta$ and TNF- $\alpha$, as well as that of APCs chemo-attractants has been shown. Thymic stromal lymphopoietin (TSLP) is also expressed by oral epithelial cells following TLR3, TLR5 and TLR2/TLR6 activation (78).

\section{EAR EPITHELIA}

Toll-like receptor expression has been detected in the ear epithelium (Table 1), indicating that this tissue is suited to respond to pathogens and initiate immune and defense responses accordingly. Primary epithelial cells of the human ear and middle ear/inner ear epithelial cell lines express functional TLR2 but not TLR4, shown by their responsiveness to Haemophilus influenzae whole cell lysates stimulation in vitro and up-regulation of defensins mRNA expression, but not to purified LPS (83). TLR2-dependent stimulation is inhibited by anti-TLR2 blocking antibodies (84). From immunohistochemistry studies of biopsies from the normal ear canal and acquired cholesteatoma (an abnormal growth of keratinized squamous epithelium), it appears that expression of TLR2, TLR3 and TLR4 is detected and regulated as a function of cholesteatoma (85). Studies on TLR expression and function in animal models support expression of TLR2, TLR4, and TLR9 in auditory cells (86).

\section{OCULAR EPITHELIA}

A larger number of studies exist regarding TLR expression in the human eye (93) as compared to the ear (Table 1). Expression of mRNA for TLR1, TLR2, TLR3, TLR4, TLR5, TLR6 and TLR9 has been shown in human corneal epithelial cells (88), where extracellular TLR 3 and intracellular TLR 2 and TLR 4 expression can be detected (6). TLR2 and TLR5 functionality in these cells has been assessed by loss-of-activity using anti-TLR 2 and -TLR 5 antibodies. It is not clear whether lack of TLR4 or MD-2 protein expression is involved in un-responsiveness to TLR4 ligands (97). Corneal epithelial cells respond to TLR stimulation mostly by secreting defensins and by further regulating expression of TLR mRNA $(87,92,94,95)$. In retinal epithelial cells, TLR2, TLR3, and TLR4 mRNA expression has been detected and is regulated by signaling via TLR3, which induces high levels of TLR3 and TLR9 protein expression $(89,100)$. Induction of interferons, IL-8 and MCP1 can be inhibited by anti-TLR3 antibodies, but stimulation via TLR9 only induces IL-8 secretion. mRNA for TLR1, TLR6, TLR7 and TLR9 and TLR4 protein expression has also been detected in section of whole human eyes and iris epithelial cells (98). Lastly, TLR9 is expressed in conjunctival epithelial cells and its expression is regulated by nerve growth factors (99). In the human eye, the major function of TLR-dependent signaling is induction of anti-microbial substances. While hBD-1 to hBD-4 are expressed constitutively, hBD-2 expression is increased by TLR2 and TLR5 stimulation for example, in a Pseudomonas aeruginosa infection model of corneal epithelial cells $(90,95)$. In the ocular epithelial tissue, expression of hBD-9 is also induced by TLR2, TLR3, TLR4 and TLR5 signaling $(150,151)$. In immortalized human eye tissue, mRNA expression and secreted IL-1 $\beta$, IL-6, IL-8, MCP1 and sICAM-1, IL-32, IL-33 and TNF- $\alpha$ are induced by TLR2, TLR3, TLR4 and TLR5 signaling in response to viral and bacterial stimulation $(91,94,96,152)$.

\section{AIRWAY EPITHELIUM}

Crucial regulation of TLR expression is well-documented in the airways (Table 1), where it critically influences airway defense mechanisms and local immune responses. While expression of TLR mRNAs is generally detected in respiratory tract epithelial cells, protein expression often varies, depending on tissue site and on host physiologic vs. disease condition (i.e., normal vs. inflammation or allergy) $(7,104)$. The most relevant TLRs in the airways epithelia are TLR2 and TLR4. Their expression is maintained at low levels and preferentially on the basal cell layers. Following infection by pathogens and in inflamed tissues, increased expression of TLR2 and TLR4 has been reported (101, 109, 110). TLR4 is often intracellular, initially located in the Golgi complex, but is readily transferred to the cell surface for pathogen recognition (112). TLR2 and TLR4 responses in the airway epithelium are also influenced by the constitutively low or absent expression of MD-2 and CD36 $(106,153)$ and by negative TLR regulatory factors such as IRAK-M and Tollip, which dampen cell activation in physiologic conditions. Exposure to TLR4 ligands, such as killed $H$. influenzae or its purified P6 outer membrane protein, to TNF- $\alpha$ and IFN- $\gamma$ can induce MD-2 expression and cell responsiveness. TLR3 and TLR5 also play important roles in the human airway epithelia by recognizing viral and bacterial ligands $(107,108)$.

Toll-like receptor-dependent activation of airway epithelial cells can induce different responses, depending on the tissue location along the respiratory tract. The upper respiratory epithelium, which includes the nasal cavity, pharynx, and the larynx, is generally in contact with a high number of (mostly commensal) organisms [up to $10^{7}$ organisms/nostril and up to $10^{8}$ organisms in the nasopharynx (154)]. The first and most common defense response in these epithelia is production of mucus. Expression of mucins, the major protein components of mucus, is induced directly, by 
TLR signaling and indirectly, by high levels of IL- 8 and TNF- $\alpha$ induced via TLRs (155). In turn, mucins can also further regulate TLR signaling (156). In epithelial cells of the nasal mucosa, TLR signaling induces production of anti-microbial substances including $\mathrm{hBD}-1$ to $\mathrm{hBD}-4$, relevant for defense mechanism in both disease conditions and allergy (103). In the lower respiratory tract, which includes the trachea, primary bronchi, and the lungs, TLRdependent responses are also regulated through expression levels and localization mechanisms. These epithelial tissues are relatively sterile but can become exposed to microorganisms descending from the upper respiratory tract. Studies of human lung epithelial tissues have shown TLR4 expression and signaling in response to bacterial LPS (112) and in disease conditions, such as chronic obstructive pulmonary disorder (COPD), asthma and allergy (103, 111). In tracheal epithelial cells, TLR3 expression on the luminal and basal side, and TLR2, TLR6 and TLR1 basolateral expression, have been reported. Low levels of TLR2, TLR4, TLR5, TLR7, TLR9 and TLR10, and high levels of TLR6 are shown, and TLR3, TLR7, and TLR9 are present in both intracellular compartments and on the cell surface (7). Also in lower respiratory tract, TLR signaling induces production of anti-microbial substances. HBD- 1 is constitutively expressed in these epithelia, hBD-5 and hBD- 6 are not expressed and increased expression of hBD-2 to hBD- 4 is observed in a TLR-dependent manner $(105,106,157)$. Besides defensins, other antibacterial molecules are induced by TLR signaling, such as lysozyme, nitric oxide (NO), and LL-37 (158). TLR signaling also leads to production of cytokines. Soluble inflammatory mediators in the upper and lower respiratory epithelia are desirable for promoting local recruitment of professional phagocytic cells that participate in pathogen clearance. Accordingly, TLR-dependent secretion of TNF- $\alpha$, IL- 8, MIP- $1 \alpha$, MIP- $1 \beta$, RANTES, GRO- $\alpha,-\beta$, and $-\gamma$, IL-6, IL-5, and TGF- $\beta$ promotes an influx of neutrophils, eosinophils, monocytes, NK cells, macrophages and DCs at these sites $(102,159)$. Secretion of type-I and type-III IFNs (including IL-28 and IL-29) is also reported, predominantly via TLR3 signaling $(7,160)$, suggesting an active protective process against viral infections. Other TLR-dependent mediators of immune responses that are induced in the airways include BAFF and APRIL, which favor interaction of airway epithelial cells with B cells and DCs (161).

\section{GUT EPITHELIUM}

The mucosal epithelial tissue of the digestive system, or gut, is tightly connected to both the oral cavity and the respiratory tract. This epithelium is also colonized by an enormous number of commensal microorganisms (approximately $10^{13}-10^{14}$ ) and occasionally, a small number of pathogens from similar species to those found in the oral and respiratory tracts. Differential TLR expression and functions are observed in epithelial cells of these tissues, depending on the specific location (i.e., the esophagus, the stomach, the small intestine or the large intestine) (Table 1), and depending on the local commensal flora in each of these tracts. Generally, mRNA for TLR1 to TLR9 has been reported, but only a low, constitutive expression of TLR2, TLR4 and TLR5 (and of MD-2) is observed on the cell basolateral side (120).

Few studies have shown TLR expression in the esophagus. TLR4 mRNA expression and functional activity in response to LPS have been shown in biopsies of cancerous and normal esophageal epithelial tissues in vitro and ex vivo (114). Esophageal epithelial cells also express high levels of TLR2 and TLR3 mRNA and, to a lower extent, TLR1 and TLR5 mRNA. Following stimulation of TLR3 with Poly I:C, TLR2 mRNA expression is up-regulated, although these cells are unresponsive to $\mathrm{PG}$ and $\mathrm{Pam}_{3} \mathrm{CSK}_{4}$. In addition, cell incubation with flagellin also fails to induce esophageal epithelial cell activation, suggesting that both TLR2 and TLR5 proteins may not be expressed. Secretion of high levels of IL-8 via TLR3 activation is consistent with responses triggered by infection with intracellular pathogens (113). Only a few studies exist on stomach epithelial cells. In normal gastric epithelial cells, constitutive and inducible expression of TLR2, TLR4 and TLR5 mRNA and protein has been shown in response to bacterial components and whole organisms $(115,116)$. Inducible expression of TLR4 and TLR2-dependent secretion of cytokines in vitro can be inhibited by blocking anti-TLR2 antibodies (117).

The small and large intestine areas present the highest concentration of commensal microorganisms as compared to all the other mucosal epithelial sites. Here, TLR expression and control of signaling pathways is extremely important. Intestinal epithelial cells (IECs) may either lack expression of TLR4, MD-2 and CD14 or, if expressed, TLR4 may be located in intracellular compartments to avoid hyper-responsiveness to LPS from commensal organisms $(118,121,122)$. Up-regulation of MD-2 and TLR4 can be induced by high local levels of IFN- $\gamma$ or TNF- $\alpha$, which is thought to contribute to chronic colitis associated with Crohn's disease (120). TLR2 mRNA and low levels of TLR2 protein are expressed in these cells at a sub-apical location and high levels of TLR5 are detected on the cell's basolateral side, thus sensing flagellin only when microorganisms cross the intestinal epithelial barrier during active invasion (119). TLR9 activation at the apical or basolateral side of IECs may induce secretion of different cytokines, depending on whether NF- $\kappa$ B pathways are triggered (123). Polar expression of TLRs is a mechanism common to the oral, airway and gut epithelia for preventing unnecessary and potentially detrimental inflammatory response to commensal colonizers. Additional control mechanisms for TLR-mediated intestinal cell activation include negative regulation of TLR signaling via Tollip and the single Ig IL-1 receptor-related molecule (SIGRR) (162).

Toll-like receptor-dependent production of $\alpha$-defensins (hD-5 and hD-6), $\beta$-defensins (hBD-1, hBD-2, and hBD-3) and other bactericidal substances has been shown in the gut (163). In contrast to the predominant induction of TLR-dependent antimicrobial products in the oral and airway epithelium, secretion of inflammatory mediators is an important outcome in the gut epithelium. Pro-inflammatory cytokines including IL-1 $\beta$, IL-7, IL-8, IL-15, and IL-18 drive local recruitment of PMNs and other leukocytes $(164,165)$, and IL-18 secretion further amplifies IL- 2 and INF- $\gamma$ production, influencing production of mucus and its composition. However, considering that an overly robust inflammatory response is detrimental to the host, gut epithelial cells also produce IL-10 and TGF- $\beta$, which play a role in tissue repair processes and re-establish the barrier function of the gut epithelia (166).

The significance of TLR-dependent cytokine production by IECs is also related to the presence of $M$ cells, Paneth cells, 
and mucus-producing goblet cells within the epithelial tissue. $\mathrm{M}$ cells, or membranous epithelial cells, are located above Peyer's patches and other lymphoid areas and provide an important bridge between epithelial cells and professional immune cells. These cells facilitate antigen sampling and transport through the epithelial layer into lymphoid areas and accelerate both innate and adaptive immune responses (167). M cells express higher levels of TLR4 on the apical surface, in contrast to enterocytes, and provide signals for further activation of immune cells to produce secretory IgA for control of both pathogens and commensals and other mediators of immunity such as BAFF and APRIL (168). Paneth cells, epithelial cells of the small intestine, express TLRs for recognition of pathogens and produce anti-microbial substances (124).

\section{GENITO-URINARY TRACT EPITHELIUM}

Toll-like receptor expression by epithelial cells of the genitourinary tract is also fine-tuned to specifically respond only to pathogens, because of the potential large number of commensal organisms in the different compartments of this mucosal site (Table 1). In this epithelium, additional variables need consideration, such as the diversity of cell composition of the reproductive tract epithelium in females vs. males, the nature of the commensal flora and the likelihood of exposure to pathogens for each anatomical section, thus suggesting a tissue-specific immune surveillance. Few studies have been carried out on the human male genital tract (MGT), while more abundant data exist on mouse and rat models (169). TLR expression in the human MGT is generally low. In different sections of the MGT, for example in the epididymis, vas deferens, seminal vesicles and testes, epithelial cells do not appear to express TLR mRNA. In the prostate, intracellular expression of TLR3 and TLR8 is detected and that of TLR9 in the penile urethra, although it is not widespread to all individual cells. In vitro studies of primary urethral and prostate cells, epididymal-vas deferens have indicated a potential cell susceptibility to activation by TLR2 ligands. Similar observations have been made in seminal vesicles (although overall TLR expression is not well-studied in these cells) $(81,125-127)$. One of the reasons for such low TLRdependent signaling in the MGT also correlates with protection of sperm cells development, which would not benefit from occurring in a pro-inflammatory environment where cells are highly responsive to stimulation via TLRs (despite protective functions against infections) (170). In addition, the commensal microflora burden of the MGT is rather low.

Toll-like receptor expression is better described in epithelial cells of the female genital tract (FGT). In vaginal epithelial cells, TLR1 to TLR6 and TLR9 are expressed, with high levels of TLR2 and TLR4 proteins $(129,130)$. In epithelial cells of upper FGT regions, TLR4 expression is not fully ascertained (133). It is likely low in the endocervical and ectocervical epithelial tissues (171) but these cells express TLR1, TLR2, and TLR6 and are responsive to TLR2 and TLR5 activation. Other reports indicate expression of mRNA for TLR7, TLR8 (weak), TLR9 and detectable protein levels of TLR3 (extracellular) and TLR9 in these cells $(130,132)$. In the sterile regions of the FGT, the fallopian tubes and uterus, TLR1, TLR7, TLR8 and TLR9 mRNA is detected, likely due to the sensitivity of these sites to viral infections (130). Uterine epithelial cells express TLR1 to TLR9 but are only susceptible to activation by TLR2, TLR3, TLR5, and to some extent, TLR4 agonists (134). Endometrial epithelial cells express TLR1 to TLR6 and TLR9, but low TLR5 and TLR6 levels are observed in isolated endometrial epithelial cells as compared to the whole tissue (130). In most of the FGT epithelia, TLR10 mRNA is also detected. Clearly, such variable expression of TLRs throughout the FGT supports different responses to potential pathogens and controls local homeostasis in the absence of infection.

Although in part physically distinct from the genital tract epithelium, cells of the urinary tract epithelia (comprising the urethra, bladder, ureters, and the kidneys) have also been shown to express TLRs. TLR2, TLR3, TLR4, TLR5, and TLR9 are expressed in various sites of the urinary tract epithelium (137), but renal epithelial cell lines and primary human proximal tubule cells do not express TLR4 and are unresponsive to LPS $(138,139)$. Expression of soluble MD-2 and CD14 also correlates with responsiveness of these cells to LPS. In the bladder and in the kidney epithelia, expression of TLR4 is an important surveillance strategy against Gram negative bacteria infections, particularly uropathogenic E. coli, controlling inflammatory responses to such infections (140). Heightened susceptibility to urinary tract infections (UTIs), asymptomatic and persistent bacteriuria have been associated to low levels of TLR4 expression and TLR4 polymorphisms in human being (135).

Although there are tissue-specific differences in TLR expression in the MGT and the FGT, production of anti-microbial substances is observed in both tissues. TLR-dependent secretion of hBD-1, DEFB118, DEFB126, and SPAG11 (172) is elicited in the epididymis, testis, and prostate (173) and that of $\mathrm{hD}-5$ and hBD-1 in the vagina, the ectocervix and at high levels particularly in the endocervix, uterus and fallopian tubes. By contrast, different patterns of cytokine and chemokine secretion characterize TLR-dependent responses in the MGT and the FGT, where the delicate balance between homeostasis and inflammation can influence fertility and reproduction processes. In the FGT, mild inflammatory responses are observed, possibly due to an intrinsic bias of this tissue to exposure to large numbers of commensals. TLR-dependent stimulation of FGT epithelial cells in vitro induces secretion of IL- $1 \alpha$, IL- $1 \beta$, IL- 6 , IL- 8 and TNF- $\alpha(64,174)$, and cyclooxygenase 2 (COX-2), an inducible enzyme associated with mucosal inflammation (131), but few studies exist to support these findings in vivo. During infection by sexually transmitted pathogens, such as Chlamydia or Neisseria gonorrhoeae, secretion of IFN- $\gamma$, IL-10, IL-12, IL- $1 \beta$, IL-6, and IL-8 has been reported in the cervix, fallopian tubes, and cervical secretions $(174,175)$. In the fallopian tubes and the uterus, the presence of endometrial epithelial cells, with similar functions than the intestinal $\mathrm{M}$ cells, favors secretion of inflammatory cytokines that can influence local immune responses (176). In epithelial cells of the MGT, data gathered mostly from in vitro studies have identified secretion of IL-6, IL-8, TNF- $\alpha$, and IL$1 \beta$ following TLR stimulation $(64,128,177)$. A consequence of genito-urinary tract epithelia inflammation, recruitment of professional APCs and PMNs to the site of infection leads to symptoms such as purulent discharge and local tissue inflammation. These symptoms are observed at varying extent in both the MGT and FGT. 


\section{CONCLUSION}

It is well established that cell activation and signaling via TLRs is crucial for induction of host immune and defense responses against microorganisms. During the course of life, human beings encounter a large number of commensal bacteria. The majority of commensals do not alter local homeostasis and integrity of the tissues that they colonize, and some have even beneficial affects at mucosal sites, for example the gut or the reproductive tract. Naturally, host mucosal epithelia are also exposed to potential pathogens. In many cases, these microorganisms only cause disease when they succeed in colonizing the appropriate infection site(s) or in crossing the mucosal epithelial barriers that separate the host from the environment. Potential pathogenicity and diseases may also arise in the event of cross-colonization of mucosal epithelial tissues by commensal organisms that are not specific for that given body site. Thus, epithelial cells of mucosal sites have evolved to implement specific control mechanisms for bacterial recognition and for initiating or suppressing local tissuespecific immune responses against disease-causing organisms or commensals, respectively. Regulation of TLR expression, cellular localization, and functions in mucosal epithelial cells provides one of the mechanisms by which bacteria/host cell interactions are directed to avoid onset of persistent local inflammation. For example, in mucosal epithelia, expression of TLRs on the cell surface is strongly regulated between the apical and basolateral sides of cells, ensuring that immune response only takes place if pathogens cross these tissues and preventing tissue damage in the absence of benefits for the host. Similarly, expression of endosomal TLRs and other cytosolic PRRs including NLRs (165) and RIG-like receptors (RLRs) (178) ensures recognition of intracellular pathogens. Thus, induction of specific responses is targeted to pathogen organisms' clearance and resolution of infection. The importance of TLR regulation is also apparent in the control of host diseases and conditions that can result from abnormal TLR expression and $t r r$ gene polymorphisms. For example, Lupus and other auto-immune conditions have been suggested to be caused, in part, by dysregulation of TLR expression (179). Host susceptibility to infections can also be linked to some TLR polymorphysms, as shown for malaria, uropathogenic E. coli, and a number of other bacterial infections $(135,136)$.

Toll-like receptor expression also can influence specific microbial communities present at mucosal epithelial sites, as shown for the gut or the genito-urinary tract. Although a number of factors likely influence the intimate relationship between host and microbes, TLRs may play a role in determining specific colonization sites for commensal bacterial. The expression and regulation of TLRs in epithelial cells is thus of critical importance for microorganisms sampling and act to direct downstream host responses and, ultimately, disease outcomes.

\section{ACKNOWLEDGMENTS}

The authors thank John F. Love, M.D., Ph.D. (Boston University) for critical reading of the manuscript. The authors thank NIH/NIAID grants U19 AI084048-01 and R01 AI40944-01.

\section{REFERENCES}

1. Sasai M, Yamamoto M. Pathogen recognition receptors: ligands and signaling pathways by toll-like receptors. Int Rev Immunol (2013) 32:116-33. doi:10.3109/08830185.2013.774391
2. Akira S, Hemmi H. Recognition of pathogen-associated molecular patterns by TLR family. Immunol Lett (2003) 85:85-95. doi:10.1016/S0165-2478(02) 00228-6

3. Cario E, Brown D, McKee M, Lynch-Devaney K, Gerken G, Podolsky DK. Commensal-associated molecular patterns induce selective toll-like receptortrafficking from apical membrane to cytoplasmic compartments in polarized intestinal epithelium. Am J Pathol (2002) 160:165-73. doi:10.1016/S00029440(10)64360-X

4. Matzinger P. Tolerance, danger, and the extended family. Annu Rev Immunol (1994) 12:991-1045. doi:10.1146/annurev.immunol.12.1.991

5. Brinkmann MM, Spooner E, Hoebe K, Beutler B, Ploegh HL, Kim YM. The interaction between the ER membrane protein UNC93B and TLR3, 7, and 9 is crucial for TLR signaling. J Cell Biol (2007) 177:265-75. doi:10.1083/jcb. 200612056

6. Ueta M, Nochi T, Jang MH, Park EJ, Igarashi O, Hino A, et al. Intracellularly expressed TLR2s and TLR4s contribution to an immunosilent environment at the ocular mucosal epithelium. J Immunol (2004) 173:3337-47. doi:10.4049/jimmunol.173.5.3337

7. Ioannidis I, Ye F, McNally B, Willette M, Flano E. Toll-like receptor expression and induction of type I and type III interferons in primary airway epithelial cells. J Virol (2013) 87:3261-70. doi:10.1128/JVI.01956- 12

8. Medzhitov R, Preston-Hurlburt P, Kopp E, Stadlen A, Chen C, Ghosh S, et al. MyD88 is an adaptor protein in the hToll/IL-1 receptor family signaling pathways. Mol Cell (1998) 2:253-8. doi:10.1016/S1097-2765(00)80136-7

9. Fitzgerald KA, Palsson-McDermott EM, Bowie AG, Jefferies CA, Mansell AS, Brady G, et al. Mal (MyD88-adapter-like) is required for toll-like receptor-4 signal transduction. Nature (2001) 413:78-83. doi:10.1038/35092578

10. Horng T, Barton GM, Medzhitov R. TIRAP: an adapter molecule in the toll signaling pathway. Nat Immunol (2001) 2:835-41. doi:10.1038/ni0901-835

11. Yamamoto M, Sato S, Hemmi H, Hoshino K, Kaisho T, Sanjo H, et al. Role of adaptor TRIF in the MyD88-independent toll-like receptor signaling pathway. Science (2003) 301(5633):640-3. doi:10.1126/science.1087262

12. Oshiumi H, Matsumoto M, Funami K, Akazawa T, Seya T. TICAM-1, an adaptor molecule that participates in toll-like receptor 3-mediated interferon-beta induction. Nat Immunol (2003) 4:161-7. doi:10.1038/ni886

13. Fitzgerald KA, Rowe DC, Barnes BJ, Caffrey DR, Visintin A, Latz E, et al. LPSTLR4 signaling to IRF-3/7 and NF- $\{$ kappa $\}$ B involves the toll adapters TRAM and TRIF. J Exp Med (2003) 198:1043-55. doi:10.1084/jem.20031023

14. Kondo T, Kawai T, Akira S. Dissecting negative regulation of toll-like receptor signaling. Trends Immunol (2012) 33:449-58. doi:10.1016/j.it.2012.05.002

15. Bell JK, Botos I, Hall PR, Askins J, Shiloach J, Davies DR, et al. The molecular structure of the TLR3 extracellular domain. J Endotoxin Res (2006) 12:375-8. doi:10.1179/096805106X118780

16. Jin MS, Kim SE, Heo JY, Lee ME, Kim HM, Paik SG, et al. Crystal structure of the TLR1-TLR2 heterodimer induced by binding of a tri-acylated lipopeptide. Cell (2007) 130:1071-82. doi:10.1016/j.cell.2007.09.008

17. Kim HM, Park BS, Kim JI, Kim SE, Lee J, Oh SC, et al. Crystal structure of the TLR4-MD-2 complex with bound endotoxin antagonist eritoran. Cell (2007) 130:906-17. doi:10.1016/j.cell.2007.08.002

18. Yoon SI, Kurnasov O, Natarajan V, Hong M, Gudkov AV, Osterman AL, et al. Structural basis of TLR5-flagellin recognition and signaling. Science (2012) 335:859-64. doi:10.1126/science.1215584

19. Tanji H, Ohto U, Shibata T, Miyake K, Shimizu T. Structural reorganization of the toll-like receptor 8 dimer induced by agonistic ligands. Science (2013) 339:1426-9. doi:10.1126/science.1229159

20. Akira S, Yamamoto M, Takeda K. Role of adapters in toll-like receptor signalling. Biochem Soc Trans (2003) 31:637-42. doi:10.1042/BST0310637

21. Gohda J, Matsumura T, Inoue J. Cutting edge: TNFR-associated factor (TRAF) 6 is essential for MyD88-dependent pathway but not toll/IL-1 receptor domain-containing adaptor-inducing IFN-beta (TRIF)-dependent pathway in TLR signaling. J Immunol (2004) 173:2913-7. doi:10.4049/jimmunol.173.5. 2913

22. Meylan E, Burns K, Hofmann K, Blancheteau V, Martinon F, Kelliher M, et al. RIP1 is an essential mediator of toll-like receptor 3-induced NF-kappa B activation. Nat Immunol (2004) 5:503-7. doi:10.1038/ni1061

23. Chen HC, Zhan X, Tran KK, Shen H. Selectively targeting the toll-like receptor 9 (TLR9) - IRF 7 signaling pathway by polymer blend particles. Biomaterials (2013) 34:6464-72. doi:10.1016/j.biomaterials.2013.05.016

24. Burns E, Eliyahu T, Uematsu S, Akira S, Nussbaum G. TLR2-dependent inflammatory response to Porphyromonas gingivalis is MyD88 independent, 
whereas MyD88 is required to clear infection. J Immunol (2010) 184:1455-62. doi:10.4049/jimmunol.0900378

25. Gao Q, Qi L, Wu T, Wang J. Clostridium butyricum activates TLR2-mediated MyD88-independent signaling pathway in HT-29 cells. Mol Cell Biochem (2012) 361:31-7. doi:10.1007/s11010-011-1084-y

26. Hacker H, Tseng PH, Karin M. Expanding TRAF function: TRAF3 as a tri-faced immune regulator. Nat Rev Immunol (2011) 11:457-68. doi:10.1038/nri2998

27. Tseng PH, Matsuzawa A, Zhang W, Mino T, Vignali DA, Karin M. Different modes of ubiquitination of the adaptor TRAF3 selectively activate the expression of type I interferons and proinflammatory cytokines. Nat Immunol (2010) 11:70-5. doi:10.1038/ni.1819

28. Alexopoulou L, Holt AC, Medzhitov R, Flavell RA. Recognition of doublestranded RNA and activation of NF-kappaB by toll-like receptor 3. Nature (2001) 413:732-8. doi:10.1038/35099560

29. Kelley SL, Lukk T, Nair SK, Tapping RI. The crystal structure of human soluble CD14 reveals a bent solenoid with a hydrophobic amino-terminal pocket. J Immunol (2013) 190:1304-11. doi:10.4049/jimmunol.1202446

30. Song WS, Hong M, Yoon SI. Purification, crystallization and X-ray crystallographic studies of flagellin from Pseudomonas aeruginosa. Acta Crystallogr F Struct Biol Commun (2014) 70:200-2. doi:10.1107/S2053230X13034286

31. Cervantes JL, La Vake CJ, Weinerman B, Luu S, O'Connell C, Verardi PH, et al. Human TLR8 is activated upon recognition of Borrelia burgdorferi RNA in the phagosome of human monocytes. J Leukoc Biol (2013) 94:1231-41. doi:10.1189/jlb.0413206

32. Chen X, Liang H, Zhang J, Zen K, Zhang CY. microRNAs are ligands of toll-like receptors. RNA (2013) 19:737-9. doi:10.1261/rna.036319.112

33. Ohto U, Tanji H, Shimizu T. Structure and function of toll-like receptor 8. Microbes Infect (2014) 16(4):273-82. doi:10.1016/j.micinf.2014.01.007

34. Kuznik A, Bencina M, Svajger U, Jeras M, Rozman B, Jerala R. Mechanism of endosomal TLR inhibition by antimalarial drugs and imidazoquinolines. J Immunol (2011) 186:4794-804. doi:10.4049/jimmunol.1000702

35. Hemmi H, Takeuchi O, Kawai T, Kaisho T, Sato S, Sanjo H, et al. A toll-like receptor recognizes bacterial DNA. Nature (2000) 408:740-5. doi:10.1038/ 35047123

36. Parroche P, Lauw FN, Goutagny N, Latz E, Monks BG, Visintin A, et al. Malaria hemozoin is immunologically inert but radically enhances innate responses by presenting malaria DNA to toll-like receptor 9. Proc Natl Acad Sci U S A (2007) 104:1919-24. doi:10.1073/pnas.0608745104

37. Regan T, Nally K, Carmody R, Houston A, Shanahan F, Macsharry J, et al. Identification of TLR10 as a key mediator of the inflammatory response to Listeria monocytogenes in intestinal epithelial cells and macrophages. J Immunol (2013) 191(12):6084-92. doi:10.4049/jimmunol.1203245

38. Lee SM, Kok KH, Jaume M, Cheung TK, Yip TF, Lai JC, et al. Toll-like receptor 10 is involved in induction of innate immune responses to influenza virus infection. Proc Natl Acad SciUS A (2014) 111:3793-8. doi:10.1073/pnas.1324266111

39. Abad C, Gonzalez-Escribano MF, Diaz-Gallo LM, Lucena-Soto JM, Marquez JL, Leo E, et al. Association of toll-like receptor 10 and susceptibility to Crohn's disease independent of NOD2. Genes Immun (2011) 12:635-42. doi:10.1038/gene.2011.41

40. Stevens VL, Hsing AW, Talbot JT, Zheng SL, Sun J, Chen J, et al. Genetic variation in the toll-like receptor gene cluster (TLR10-TLR1-TLR6) and prostate cancer risk. Int J Cancer (2008) 123:2644-50. doi:10.1002/ijc.23826

41. Park BS, Lee JO. Recognition of lipopolysaccharide pattern by TLR4 complexes. Exp Mol Med (2013) 45:e66. doi:10.1038/emm.2013.97

42. Netea MG, van DM, Kullberg BJ, Cavaillon JM, Van der Meer JW. Does the shape of lipid A determine the interaction of LPS with toll-like receptors? Trends Immunol (2002) 23:135-9. doi:10.1016/S1471-4906(01)02169-X

43. Carpenter S, Carlson T, Dellacasagrande J, Garcia A, Gibbons S, Hertzog P, et al. TRIL, a functional component of the TLR4 signaling complex, highly expressed in brain. J Immunol (2009) 183:3989-95. doi:10.4049/jimmunol.0901518

44. Kocgozlu L, Elkaim R, Tenenbaum H, Werner S. Variable cell responses to P. gingivalis lipopolysaccharide. J Dent Res (2009) 88:741-5. doi:10.1177/ 0022034509341166

45. Biragyn A, Ruffini PA, Leifer CA, Klyushnenkova E, Shakhov A, Chertov O, et al. Toll-like receptor 4-dependent activation of dendritic cells by beta-defensin 2 . Science (2002) 298:1025-9. doi:10.1126/science.1075565

46. Park JS, Svetkauskaite D, He Q, Kim JY, Strassheim D, Ishizaka A, et al. Involvement of toll-like receptors 2 and 4 in cellular activation by high mobility group box 1 protein. J Biol Chem (2004) 279:7370-7. doi:10.1074/ jbc.M306793200

47. Peri F, Calabrese V. Toll-like receptor 4 (TLR4) modulation by synthetic and natural compounds: an update. J Med Chem (2013) 57(9):3612-22. doi:10.1021/jm401006s

48. Takeuchi O, Sato S, Horiuchi T, Hoshino K, Takeda K, Dong Z, et al. Cutting edge: role of toll-like receptor 1 in mediating immune response to microbial lipoproteins. J Immunol (2002) 169:10-4. doi:10.4049/jimmunol.169.1.10

49. Takeuchi O, Kawai T, Muhlradt PF, Morr M, Radolf JD, Zychlinsky A, et al. Discrimination of bacterial lipoproteins by toll-like receptor 6. Int Immunol (2001) 13:933-40. doi:10.1093/intimm/13.7.933

50. Buwitt-Beckmann U, Heine H, Wiesmuller KH, Jung G, Brock R, Akira S, et al. Toll-like receptor 6-independent signaling by diacylated lipopeptides. Eur J Immunol (2005) 35:282-9. doi:10.1002/eji.200424955

51. van BJ, Plantinga TS, Joosten LA, Netea MG, Folkerts G, Kraneveld AD, et al. TLR2 \& Co: a critical analysis of the complex interactions between TLR2 and coreceptors. J Leukoc Biol (2013) 94:885-902. doi:10.1189/jlb.0113003

52. Ranoa DR, Kelley SL, Tapping RI. Human lipopolysaccharide-binding protein (LBP) and CD14 independently deliver triacylated lipoproteins to toll-like receptor 1 (TLR1) and TLR2 and enhance formation of the ternary signaling complex. J Biol Chem (2013) 288:9729-41. doi:10.1074/jbc.M113.453266

53. Schroder NW, Morath S, Alexander C, Hamann L, Hartung T, Zahringer U, et al. Lipoteichoic acid (LTA) of S. pneumoniae and S. aureus activates immune cells via toll-like receptor (TLR)-2, LPS binding protein (LBP) and CD14 while TLR-4 and MD-2 are not involved. J Biol Chem (2003) 278(18):15587-94. doi:10.1074/jbc.M212829200

54. Tapping RI, Tobias PS. Mycobacterial lipoarabinomannan mediates physical interactions between TLR1 and TLR2 to induce signaling. J Endotoxin Res (2003) 9:264-8. doi:10.1179/096805103225001477

55. Yadav M, Schorey JS. The beta-glucan receptor dectin-1 functions together with TLR2 to mediate macrophage activation by mycobacteria. Blood (2006) 108:3168-75. doi:10.1182/blood-2006-05-024406

56. Sato M, Sano H, Iwaki D, Kudo K, Konishi M, Takahashi H, et al. Direct binding of toll-like receptor 2 to zymosan, and zymosan-induced NF-kappa B activation and TNF-alpha secretion are down-regulated by lung collectin surfactant protein A. J Immunol (2003) 171:417-25. doi:10.4049/jimmunol.171.1.417

57. Kang JY, Nan X, Jin MS, Youn SJ, Ryu YH, Mah S, et al. Recognition of lipopeptide patterns by toll-like receptor 2-toll-like receptor 6 heterodimer. Immunity (2009) 31:873-84. doi:10.1016/j.immuni.2009.09.018

58. Travassos LH, Girardin SE, Philpott DJ, Blanot D, Nahori MA, Werts C, et al. Toll-like receptor 2-dependent bacterial sensing does not occur via peptidoglycan recognition. EMBO Rep (2004) 5:1000-6. doi:10.1038/sj.embor.7400248

59. Williams A, Flavell RA, Eisenbarth SC. The role of NOD-like receptors in shaping adaptive immunity. Curr Opin Immunol (2010) 22:34-40. doi:10.1016/j. coi.2010.01.004

60. Massari P, Visintin A, Gunawardana J, Halmen KA, King CA, Golenbock DT, et al. Meningococcal porin PorB binds to TLR2 and requires TLR1 for signaling. J Immunol (2006) 176:2373-80. doi:10.4049/jimmunol.176.4.2373

61. Liu X, Wetzler LM, Nascimento LO, Massari P. Human airway epithelial cell responses to Neisseria lactamica and purified porin via toll-like receptor 2-dependent signaling. Infect Immun (2010) 78:5314-23. doi:10.1128/IAI. 00681-10

62. Toussi DN, Carraway M, Wetzler LM, Lewis LA, Liu X, Massari P. The amino acid sequence of Neisseria lactamica PorB surface-exposed loops influences toll-like receptor 2-dependent cell activation. Infect Immun (2012) 80:3417-28. doi:10.1128/IAI.00683-12

63. Toussi DN, Liu X, Massari P. The FomA porin from Fusobacterium nucleatum is a toll-like receptor 2 agonist with immune adjuvant activity. Clin Vaccine Immunol (2012) 19:1093-101. doi:10.1128/CVI.00236-12

64. Massari P, Toussi DN, Tifrea DF, de la Maza LM. Toll-like receptor 2-dependent activity of native major outer membrane protein proteosomes of Chlamydia trachomatis. Infect Immun (2013) 81:303-10. doi:10.1128/IAI.01062-12

65. Biswas A, Banerjee P, Mukherjee G, Biswas T. Porin of Shigella dysenteriae activates mouse peritoneal macrophage through toll-like receptors 2 and 6 to induce polarized type I response. Mol Immunol (2007) 44:812-20. doi:10.1016/j.molimm.2006.04.007

66. Moreno-Eutimio MA, Tenorio-Calvo A, Pastelin-Palacios R, Perez-Shibayama C, Gil-Cruz C, Lopez-Santiago R, et al. Salmonella typhi OmpS1 and OmpS2 
porins are potent protective immunogens with adjuvant properties. Immunology (2013) 139:459-71. doi:10.1111/imm.12093

67. Galdiero M, Galdiero M, Finamore E, Rossano F, Gambuzza M, Catania $\mathrm{MR}$, et al. Haemophilus influenzae porin induces toll-like receptor 2-mediated cytokine production in human monocytes and mouse macrophages. Infect Immun (2004) 72:1204-9. doi:10.1128/IAI.72.2.1204-1209.2004

68. Cody V, Pace J, Nawar HF, King-Lyons N, Liang S, Connell TD, et al. Structureactivity correlations of variant forms of the B pentamer of Escherichia coli type II heat-labile enterotoxin LT-IIb with toll-like receptor 2 binding. Acta Crystallogr D Biol Crystallogr (2012) 68:1604-12. doi:10.1107/ S0907444912038917

69. Davey M, Liu X, Ukai T, Jain V, Gudino C, Gibson FC III, et al. Bacterial fimbriae stimulate proinflammatory activation in the endothelium through distinct TLRs. J Immunol (2008) 180:2187-95. doi:10.4049/jimmunol.180.4.2187

70. Nair S, Ramaswamy PA, Ghosh S, Joshi DC, Pathak N, Siddiqui I, et al. The PPE18 of Mycobacterium tuberculosis interacts with TLR2 and activates IL10 induction in macrophage. J Immunol (2009) 183:6269-81. doi:10.4049/ jimmunol.0901367

71. Beklen A, Hukkanen M, Richardson R, Konttinen YT. Immunohistochemical localization of toll-like receptors 1-10 in periodontitis. Oral Microbiol Immunol (2008) 23:425-31. doi:10.1111/j.1399-302X.2008.00448.x

72. Semlali A, Witoled C, Alanazi M, Rouabhia M. Whole cigarette smoke increased the expression of TLRs, HBDs, and proinflammory cytokines by human gingival epithelial cells through different signaling pathways. PLoS One (2012) 7:e52614. doi:10.1371/journal.pone.0052614

73. Uehara A, Fujimoto Y, Fukase K, Takada H. Various human epithelial cells express functional toll-like receptors, NOD1 and NOD2 to produce antimicrobial peptides, but not proinflammatory cytokines. Mol Immunol (2007) 44:3100-11. doi:10.1016/j.molimm.2007.02.007

74. Siponen M, Kauppila JH, Soini Y, Salo T. TLR4 and TLR9 are induced in oral lichen planus. J Oral Pathol Med (2012) 41:741-7. doi:10.1111/j.1600-0714. 2012.01169.x

75. Janardhanam SB, Prakasam S, Swaminathan VT, Kodumudi KN, Zunt SL, Srinivasan M. Differential expression of TLR-2 and TLR-4 in the epithelial cells in oral lichen planus. Arch Oral Biol (2012) 57:495-502. doi:10.1016/j. archoralbio.2011.10.013

76. Promsudthi A, Poomsawat S, Limsricharoen W. The role of toll-like receptor 2 and 4 in gingival tissues of chronic periodontitis subjects with type 2 diabetes. J Periodontal Res (2013) 49(3):346-54. doi:10.1111/jre.12112

77. Beklen A, Sorsa T, Konttinen YT. Toll-like receptors 2 and 5 in human gingival epithelial cells co-operate with T-cell cytokine interleukin-17. Oral Microbiol Immunol (2009) 24:38-42. doi:10.1111/j.1399-302X.2008.00473.x

78. Takai T, Chen X, Xie Y, Vu AT, Le TA, Kinoshita H, et al. TSLP expression induced via toll-like receptor pathways in human keratinocytes. Methods Enzymol (2014) 535:371-87. doi:10.1016/B978-0-12-397925-4.00021-3

79. Kim Y, Jo AR, Jang DH, Cho YJ, Chun J, Min BM, et al. Toll-like receptor 9 mediates oral bacteria-induced IL- 8 expression in gingival epithelial cells. Immunol Cell Biol (2012) 90:655-63. doi:10.1038/icb.2011.85

80. Manoussakis MN, Spachidou MP, Maratheftis CI. Salivary epithelial cells from Sjogren's syndrome patients are highly sensitive to anoikis induced by TLR-3 ligation. J Autoimmun (2010) 35:212-8. doi:10.1016/j.jaut.2010.06.010

81. Nishimura M, Naito S. Tissue-specific mRNA expression profiles of human toll-like receptors and related genes. Biol Pharm Bull (2005) 28:886-92. doi:10.1248/bpb.28.886

82. Lange MJ, Lasiter JC, Misfeldt ML. Toll-like receptors in tonsillar epithelial cells. Int J Pediatr Otorhinolaryngol (2009) 73:613-21. doi:10.1016/j.ijporl.2008.12. 013

83. Lim DJ, Moon SK. Establishment of cell lines from the human middle and inner ear epithelial cells. Adv Exp Med Biol (2011) 720:15-25. doi:10.1007/ 978-1-4614-0254-1_2

84. Lee HY, Takeshita T, Shimada J, Akopyan A, Woo JI, Pan H, et al. Induction of beta defensin 2 by NTHi requires TLR2 mediated MyD88 and IRAK-TRAF6p38MAPK signaling pathway in human middle ear epithelial cells. BMC Infect Dis (2008) 8:87. doi:10.1186/1471-2334-8-87

85. Szczepanski M, Szyfter W, Jenek R, Wrobel M, Lisewska IM, Zeromski J. Toll-like receptors 2, 3 and 4 (TLR-2, TLR-3 and TLR-4) are expressed in the microenvironment of human acquired cholesteatoma. Eur Arch Otorhinolaryngol (2006) 263:603-7. doi:10.1007/s00405-006-0030-1
86. Tanigawa T, Odkhuu E, Morikawa A, Hayashi K, Sato T, Shibata R, et al. Immunological role of prostaglandin $\mathrm{E} 2$ production in mouse auditory cells in response to LPS. Innate Immun (2013). doi:10.1177/1753425913503578

87. Redfern RL, Reins RY, McDermott AM. Toll-like receptor activation modulates antimicrobial peptide expression by ocular surface cells. Exp Eye Res (2011) 92:209-20. doi:10.1016/j.exer.2010.12.005

88. Erdinest N, Aviel G, Moallem E, Anteby I, Yahalom C, Mechoulam H, et al. Expression and activation of toll-like receptor 3 and toll-like receptor 4 on human corneal epithelial and conjunctival fibroblasts. J Inflamm (Lond) (2014) 11:3. doi:10.1186/1476-9255-11-3

89. Ebihara N, Yamagami S, Chen L, Tokura T, Iwatsu M, Ushio H, et al. Expression and function of toll-like receptor-3 and -9 in human corneal myofibroblasts. Invest Ophthalmol Vis Sci (2007) 48:3069-76. doi:10.1167/iovs.06-0968

90. Kumar A, Zhang J, Yu FS. Toll-like receptor 2-mediated expression of betadefensin-2 in human corneal epithelial cells. Microbes Infect (2006) 8:380-9. doi:10.1016/j.micinf.2005.07.006

91. Du JW, Zhang F, Capo-Aponte JE, Tachado SD, Zhang J, Yu FS, et al. AsialoGM1-mediated IL-8 release by human corneal epithelial cells requires coexpression of TLR5. Invest Ophthalmol Vis Sci (2006) 47:4810-8. doi:10. 1167/iovs.06-0250

92. Ma P, Wang Z, Pflugfelder SC, Li DQ. Toll-like receptors mediate induction of peptidoglycan recognition proteins in human corneal epithelial cells. Exp Eye Res (2010) 90:130-6. doi:10.1016/j.exer.2009.09.021

93. Pearlman E, Sun Y, Roy S, Karmakar M, Hise AG, Szczotka-Flynn L, et al. Host defense at the ocular surface. Int Rev Immunol (2013) 32:4-18. doi:10.3109/ 08830185.2012 .749400

94. Zhang J, Xu K, Ambati B, Yu FS. Toll-like receptor 5-mediated corneal epithelial inflammatory responses to Pseudomonas aeruginosa flagellin. Invest Ophthalmol Vis Sci (2003) 44:4247-54. doi:10.1167/iovs.03-0219

95. Evans DJ, Fleiszig SM. Why does the healthy cornea resist Pseudomonas aeruginosa infection? Am J Ophthalmol (2013) 155:961-70. doi:10.1016/j.ajo.2013. 03.001

96. Zhao J, Wu XY. Aspergillus fumigatus antigens activate immortalized human corneal epithelial cells via toll-like receptors 2 and 4. Curr Eye Res (2008) 33:447-54. doi:10.1080/02713680802130339

97. Zhang J, Kumar A, Wheater M, Yu FS. Lack of MD-2 expression in human corneal epithelial cells is an underlying mechanism of lipopolysaccharide (LPS) unresponsiveness. Immunol Cell Biol (2009) 87:141-8. doi:10.1038/icb.2008.75

98. Brito BE, Zamora DO, Bonnah RA, Pan Y, Planck SR, Rosenbaum JT. Toll-like receptor 4 and CD14 expression in human ciliary body and TLR-4 in human iris endothelial cells. Exp Eye Res (2004) 79:203-8. doi:10.1016/j.exer.2004.03.012

99. Micera A, Stampachiacchiere B, Normando EM, Lambiase A, Bonini S, Bonini S. Nerve growth factor modulates toll-like receptor (TLR) 4 and 9 expression in cultured primary VKC conjunctival epithelial cells. Mol Vis (2009) 15:2037-44.

100. Kumar MV, Nagineni CN, Chin MS, Hooks JJ, Detrick B. Innate immunity in the retina: toll-like receptor (TLR) signaling in human retinal pigment epithelial cells. J Neuroimmunol (2004) 153:7-15. doi:10.1016/j.jneuroim.2004. 04.018

101. Dong Z, Yang Z, Wang C. Expression of TLR2 and TLR4 messenger RNA in the epithelial cells of the nasal airway. Am J Rhinol (2005) 19(3):236-9.

102. Ohkuni T, Kojima T, Ogasawara N, Masaki T, Fuchimoto J, Kamekura R, et al. Poly(I:C) reduces expression of JAM-A and induces secretion of IL- 8 and TNFalpha via distinct NF-kappaB pathways in human nasal epithelial cells. Toxicol Appl Pharmacol (2011) 250:29-38. doi:10.1016/j.taap.2010.09.023

103. Ryu JH, Yoo JY, Kim MJ, Hwang SG, Ahn KC, Ryu JC, et al. Distinct TLR-mediated pathways regulate house dust mite-induced allergic disease in the upper and lower airways. J Allergy Clin Immunol (2013) 131:549-61. doi:10.1016/j.jaci.2012.07.050

104. Sha Q, Truong-Tran AQ, Plitt JR, Beck LA, Schleimer RP. Activation of airway epithelial cells by toll-like receptor agonists. Am J Respir Cell Mol Biol (2004) 31:358-64. doi:10.1165/rcmb.2003-0388OC

105. Wang X, Zhang Z, Louboutin JP, Moser C, Weiner DJ, Wilson JM. Airway epithelia regulate expression of human beta-defensin 2 through toll-like receptor 2. FASEB J (2003) 17(12):1727-9. doi:10.1096/fj.02-0616fje

106. Jia HP, Kline JN, Penisten A, Apicella MA, Gioannini TL, Weiss J, et al. Endotoxin responsiveness of human airway epithelia is limited by low expression of MD-2. Am J Physiol Lung Cell Mol Physiol (2004) 287:L428-37. doi:10.1152/ajplung.00377.2003 
107. Berube J, Bourdon C, Yao Y, Rousseau S. Distinct intracellular signaling pathways control the synthesis of IL-8 and RANTES in TLR1/TLR2, TLR3 or NOD1 activated human airway epithelial cells. Cell Signal (2009) 21:448-56. doi:10.1016/j.cellsig.2008.12.001

108. Zhang Z, Louboutin JP, Weiner DJ, Goldberg JB, Wilson JM. Human airway epithelial cells sense Pseudomonas aeruginosa infection via recognition of flagellin by toll-like receptor 5. Infect Immun (2005) 73:7151-60. doi:10.1128/IAI.73.11.7151-7160.2005

109. Armstrong L, Medford AR, Uppington KM, Robertson J, Witherden IR, Tetley TD, et al. Expression of functional toll-like receptor-2 and -4 on alveolar epithelial cells. Am J Respir Cell Mol Biol (2004) 31:241-5. doi:10.1165/rcmb. 2004-0078OC

110. Regueiro V, Moranta D, Campos MA, Margareto J, Garmendia J, Bengoechea JA. Klebsiella pneumoniae increases the levels of toll-like receptors 2 and 4 in human airway epithelial cells. Infect Immun (2009) 77:714-24. doi:10.1128/IAI.00852-08

111. MacRedmond RE, Greene CM, Dorscheid DR, McElvaney NG, O’Neill SJ. Epithelial expression of TLR4 is modulated in COPD and by steroids, salmeterol and cigarette smoke. Respir Res (2007) 8:84. doi:10.1186/1465-9921-8-84

112. Guillot L, Medjane S, Le Barillec K, Balloy V, Danel C, Chignard M, et al. Response of human pulmonary epithelial cells to lipopolysaccharide involves toll-like receptor 4 (TLR4)-dependent signaling pathways: evidence for an intracellular compartmentalization of TLR4. J Biol Chem (2004) 279:2712-8. doi:10.1074/jbc.M305790200

113. Lim DM, Narasimhan S, Michaylira CZ, Wang ML. TLR3-mediated NF\{kappa\}B signaling in human esophageal epithelial cells. Am J Physiol Gastrointest Liver Physiol (2009) 297:G1172-80. doi:10.1152/ajpgi.00065.2009

114. Verbeek RE, Siersema PD, Ten Kate FJ, Fluiter K, Souza RF, Vleggaar FP, et al. Toll-like receptor 4 activation in Barrett's esophagus results in a strong increase in COX-2 expression. J Gastroenterol (2013). doi:10.1007/s00535-013-0862-6

115. Pimentel-Nunes P, Afonso L, Lopes P, Roncon-Albuquerque R Jr., Goncalves N, Henrique R, et al. Increased expression of toll-like receptors (TLR) 2, 4 and 5 in gastric dysplasia. Pathol Oncol Res (2011) 17:677-83. doi:10.1007/s12253011-9368-9

116. Pimentel-Nunes P, Goncalves N, Boal-Carvalho I, Afonso L, Lopes P, RonconAlbuquerque R Jr., et al. Helicobacter pylori induces increased expression of toll-like receptors and decreased toll-interacting protein in gastric mucosa that persists throughout gastric carcinogenesis. Helicobacter (2013) 18:22-32. doi:10.1111/hel.12008

117. Takenaka R, Yokota K, Ayada K, Mizuno M, Zhao Y, Fujinami Y, et al. Helicobacter pylori heat-shock protein 60 induces inflammatory responses through the toll-like receptor-triggered pathway in cultured human gastric epithelial cells. Microbiology (2004) 150:3913-22. doi:10.1099/mic.0.27527-0

118. Naik S, Kelly EJ, Meijer L, Pettersson S, Sanderson IR. Absence of toll-like receptor 4 explains endotoxin hyporesponsiveness in human intestinal epithelium. J Pediatr Gastroenterol Nutr (2001) 32:449-53. doi:10.1097/00005176200104000-00011

119. Eaves-Pyles T, Bu HF, Tan XD, Cong Y, Patel J, Davey RA, et al. Luminal-applied flagellin is internalized by polarized intestinal epithelial cells and elicits immune responses via the TLR5 dependent mechanism. PLoS One (2011) 6:e24869. doi:10.1371/journal.pone.0024869

120. Vamadevan AS, Fukata M, Arnold ET, Thomas LS, Hsu D, Abreu MT. Regulation of toll-like receptor 4-associated MD-2 in intestinal epithelial cells: a comprehensive analysis. Innate Immun (2010) 16:93-103. doi:10.1177/ 1753425909339231

121. Biswas A, Wilmanski J, Forsman H, Hrncir T, Hao L, Tlaskalova-Hogenova $\mathrm{H}$, et al. Negative regulation of toll-like receptor signaling plays an essential role in homeostasis of the intestine. Eur J Immunol (2011) 41:182-94. doi:10.1002/eji.201040479

122. Hornef MW, Frisan T, Vandewalle A, Normark S, Richter-Dahlfors A. Tolllike receptor 4 resides in the Golgi apparatus and colocalizes with internalized lipopolysaccharide in intestinal epithelial cells. J Exp Med (2002) 195:559-70. doi:10.1084/jem.20011788

123. Lee J, Mo JH, Katakura K, Alkalay I, Rucker AN, Liu YT, et al. Maintenance of colonic homeostasis by distinctive apical TLR9 signalling in intestinal epithelial cells. Nat Cell Biol (2006) 8:1327-36. doi:10.1038/ncb1500

124. Menendez A, Willing BP, Montero M, Wlodarska M, So CC, Bhinder G, et al. Bacterial stimulation of the TLR-MyD88 pathway modulates the homeostatic expression of ileal Paneth cell alpha-defensins. J Innate Immun (2013) 5:39-49. doi:10.1159/000341630

125. Pudney J, Anderson DJ. Expression of toll-like receptors in genital tract tissues from normal and HIV-infected men. Am J Reprod Immunol (2011) 65:28-43. doi:10.1111/j.1600-0897.2010.00877.x

126. Mackern-Oberti JP, Motrich RD, Breser ML, Sanchez LR, Cuffini C, Rivero VE. Chlamydia trachomatis infection of the male genital tract: an update. J Reprod Immunol (2013) 100:37-53. doi:10.1016/j.jri.2013.05.002

127. Sellami H, Said-Sadier N, Znazen A, Gdoura R, Ojcius DM, Hammami A. Chlamydia trachomatis infection increases the expression of inflammatory tumorigenic cytokines and chemokines as well as components of the toll-like receptor and NF-kappaB pathways in human prostate epithelial cells. Mol Cell Probes (2014) 28(4):147-54. doi:10.1016/j.mcp.2014.01.006

128. Mackern-Oberti JP, Maccioni M, Cuffini C, Gatti G, Rivero VE. Susceptibility of prostate epithelial cells to Chlamydia muridarum infection and their role in innate immunity by recruitment of intracellular toll-like receptors 4 and 2 and MyD88 to the inclusion. Infect Immun (2006) 74:6973-81. doi:10.1128/IAI.00593-06

129. Pivarcsi A, Nagy I, Koreck A, Kis K, Kenderessy-Szabo A, Szell M, et al. Microbial compounds induce the expression of pro-inflammatory cytokines, chemokines and human beta-defensin-2 in vaginal epithelial cells. Microbes Infect (2005) 7:1117-27. doi:10.1016/j.micinf.2005.03.016

130. Fazeli A, Bruce C, Anumba DO. Characterization of toll-like receptors in the female reproductive tract in humans. Hum Reprod (2005) 20:1372-8. doi:10.1093/humrep/deh775

131. Joseph T, Zalenskaya IA, Yousefieh N, Schriver SD, Cote LC, Chandra N, et al. Induction of cyclooxygenase (COX)-2 in human vaginal epithelial cells in response to TLR ligands and TNF-alpha. Am J Reprod Immunol (2012) 67:482-90. doi:10.1111/j.1600-0897.2011.01099.x

132. Sathe A, Reddy KV. TLR9 and RIG-I signaling in human endocervical epithelial cells modulates inflammatory responses of macrophages and dendritic cells in vitro. PLoS One (2014) 9:e83882. doi:10.1371/journal.pone.0083882

133. Hart KM, Murphy AJ, Barrett KT, Wira CR, Guyre PM, Pioli PA. Functional expression of pattern recognition receptors in tissues of the human female reproductive tract. J Reprod Immunol (2009) 80:33-40. doi:10.1016/j.jri.2008. 12.004

134. Schaefer TM, Fahey JV, Wright JA, Wira CR. Innate immunity in the human female reproductive tract: antiviral response of uterine epithelial cells to the TLR3 agonist poly(I:C). J Immunol (2005) 174:992-1002. doi:10.4049/ jimmunol.174.2.992

135. Yin X, Hou T, Liu Y, Chen J, Yao Z, Ma C, et al. Association of toll-like receptor 4 gene polymorphism and expression with urinary tract infection types in adults. PLoS One (2010) 5:e14223. doi:10.1371/journal.pone.0014223

136. Netea MG, Wijmenga C, O’Neill LA. Genetic variation in toll-like receptors and disease susceptibility. Nat Immunol (2012) 13:535-42. doi:10.1038/ni.2284

137. Song J, Abraham SN. TLR-mediated immune responses in the urinary tract. Curr Opin Microbiol (2008) 11:66-73. doi:10.1016/j.mib.2007.12.001

138. Backhed F, Meijer L, Normark S, Richter-Dahlfors A. TLR4-dependent recognition of lipopolysaccharide by epithelial cells requires sCD14. Cell Microbiol (2002) 4:493-501. doi:10.1046/j.1462-5822.2002.00208.x

139. Miyazaki J, Kawai K, Oikawa T, Johraku A, Hattori K, Shimazui T, et al. Uroepithelial cells can directly respond to Mycobacterium bovis bacillus CalmetteGuerin through toll-like receptor signalling. BJU Int (2006) 97:860-4. doi:10. 1111/j.1464-410X.2006.06026.x

140. Zhang D, Zhang G, Hayden MS, Greenblatt MB, Bussey C, Flavell RA, et al. A toll-like receptor that prevents infection by uropathogenic bacteria. Science (2004) 303:1522-6. doi:10.1126/science.1094351

141. Svanborg C, Godaly G, Hedlund M. Cytokine responses during mucosal infections: role in disease pathogenesis and host defence. Curr Opin Microbiol (1999) 2:99-105. doi:10.1016/S1369-5274(99)80017-4

142. McNamara PS, Fonceca AM, Howarth D, Correia JB, Slupsky JR, Trinick RE, et al. Respiratory syncytial virus infection of airway epithelial cells, in vivo and in vitro, supports pulmonary antibody responses by inducing expression of the B cell differentiation factor BAFF. Thorax (2013) 68:76-81. doi:10.1136/thoraxjnl-2012-202288

143. Woo SJ, Im J, Jeon JH, Kang SS, Lee MH, Yun $\mathrm{CH}$, et al. Induction of BAFF expression by IFN-gamma via JAK/STAT signaling pathways in human intestinal epithelial cells. J Leukoc Biol (2013) 93:363-8. doi:10.1189/jlb.0412210 
144. Scott DA, Krauss J. Neutrophils in periodontal inflammation. Front Oral Biol (2012) 15:56-83. doi:10.1159/000329672

145. Liu J, Chen J, Du X, Hu L, Chen L. The expression of hBDs in the gingival tissue and keratinocytes from healthy subjects and periodontitis patients. Arch Oral Biol (2014) 59:193-8. doi:10.1016/j.archoralbio.2013.11.007

146. Lu Q, Darveau RP, Samaranayake LP, Wang CY, Jin L. Differential modulation of human $\{$ beta\}-defensins expression in human gingival epithelia by Porphyromonas gingivalis lipopolysaccharide with tetra- and penta-acylated lipid A structures. Innate Immun (2009) 15:325-35. doi:10.1177/1753425909104899

147. Hazlett L, Wu M. Defensins in innate immunity. Cell Tissue Res (2011) 343:175-88. doi:10.1007/s00441-010-1022-4

148. Chung WO, Dale BA. Differential utilization of nuclear factor-kappaB signaling pathways for gingival epithelial cell responses to oral commensal and pathogenic bacteria. Oral Microbiol Immunol (2008) 23:119-26. doi:10.1111/j.1399302X.2007.00398.x

149. Uehara A, Sugawara S, Takada H. Priming of human oral epithelial cells by interferon-gamma to secrete cytokines in response to lipopolysaccharides, lipoteichoic acids and peptidoglycans. J Med Microbiol (2002) 51:626-34.

150. Mohammed I, Suleman H, Otri AM, Kulkarni BB, Chen P, Hopkinson A, et al. Localization and gene expression of human beta-defensin 9 at the human ocular surface epithelium. Invest Ophthalmol Vis Sci (2010) 51:4677-82. doi:10.1167/iovs.10-5334

151. Otri AM, Mohammed I, Al-Aqaba MA, Fares U, Peng C, Hopkinson A, et al. Variable expression of human beta defensins 3 and 9 at the human ocular surface in infectious keratitis. Invest Ophthalmol Vis Sci (2012) 53:757-61. doi:10.1167/iovs.11-8467

152. Zhang L, Che C, Lin J, Liu K, Li DQ, Zhao G. TLR-mediated induction of proinflammatory cytokine IL-32 in corneal epithelium. Curr Eye Res (2013) 38:630-8. doi:10.3109/02713683.2012.763102

153. Ohnishi T, Muroi M, Tanamoto K. The lipopolysaccharide-recognition mechanism in cells expressing TLR4 and CD14 but lacking MD-2. FEMS Immunol Med Microbiol (2007) 51:84-91. doi:10.1111/j.1574-695X.2007.00281.x

154. Frank DN, Feazel LM, Bessesen MT, Price CS, Janoff EN, Pace NR. The human nasal microbiota and Staphylococcus aureus carriage. PLoS One (2010) 5:e10598. doi:10.1371/journal.pone.0010598

155. Bautista MV, Chen Y, Ivanova VS, Rahimi MK, Watson AM, Rose MC. IL-8 regulates mucin gene expression at the posttranscriptional level in lung epithelial cells. J Immunol (2009) 183:2159-66. doi:10.4049/jimmunol.0803022

156. Ueno K, Koga T, Kato K, Golenbock DT, Gendler SJ, Kai H, et al. MUC1 mucin is a negative regulator of toll-like receptor signaling. Am J Respir Cell Mol Biol (2008) 38:263-8. doi:10.1165/rcmb.2007-0336RC

157. Alekseeva L, Huet D, Femenia F, Mouyna I, Abdelouahab M, Cagna A, et al Inducible expression of beta defensins by human respiratory epithelial cells exposed to Aspergillus fumigatus organisms. BMC Microbiol (2009) 9:33. doi:10.1186/1471-2180-9-33

158. Bals R, Wang X, Zasloff M, Wilson JM. The peptide antibiotic LL-37/hCAP-18 is expressed in epithelia of the human lung where it has broad antimicrobial activity at the airway surface. Proc Natl Acad Sci U S A (1998) 95:9541-6. doi:10.1073/pnas.95.16.9541

159. Wu CA, Peluso JJ, Zhu L, Lingenheld EG, Walker ST, Puddington L. Bronchial epithelial cells produce IL-5: implications for local immune responses in the airways. Cell Immunol (2010) 264:32-41. doi:10.1016/j.cellimm.2010.04.008

160. Levy DE, Marie IJ, Durbin JE. Induction and function of type I and III interferon in response to viral infection. Curr Opin Virol (2011) 1:476-86. doi:10.1016/j.coviro.2011.11.001

161. Kato A, Truong-Tran AQ, Scott AL, Matsumoto K, Schleimer RP. Airway epithelial cells produce B cell-activating factor of TNF family by an IFNbeta-dependent mechanism. J Immunol (2006) 177:7164-72. doi:10.4049/ jimmunol.177.10.7164

162. Wald D, Qin J, Zhao Z, Qian Y, Naramura M, Tian L, et al. SIGIRR, a negative regulator of toll-like receptor-interleukin 1 receptor signaling. Nat Immunol (2003) 4:920-7. doi:10.1038/ni968

163. Ostaff MJ, Stange EF, Wehkamp J. Antimicrobial peptides and gut microbiota in homeostasis and pathology. EMBO Mol Med (2013) 5:1465-83. doi:10.1002/emmm.201201773

164. Bahrami B, Macfarlane S, Macfarlane GT. Induction of cytokine formation by human intestinal bacteria in gut epithelial cell lines. J Appl Microbiol (2011) 110:353-63. doi:10.1111/j.1365-2672.2010.04889.x
165. Wells JM, Rossi O, Meijerink M, van BP. Epithelial crosstalk at the microbiotamucosal interface. Proc Natl Acad Sci U S A (2011) 108(Suppl 1):4607-14. doi:10.1073/pnas.1000092107

166. Jarry A, Bossard C, Bou-Hanna C, Masson D, Espaze E, Denis MG, et al. Mucosal IL-10 and TGF-beta play crucial roles in preventing LPS-driven, IFNgamma-mediated epithelial damage in human colon explants. J Clin Invest (2008) 118:1132-42. doi:10.1172/JCI32140

167. Mach J, Hshieh T, Hsieh D, Grubbs N, Chervonsky A. Development of intestinal M cells. Immunol Rev (2005) 206:177-89. doi:10.1111/j.0105-2896.2005 00281.x

168. Mora JR, Iwata M, Eksteen B, Song SY, Junt T, Senman B, et al. Generation of gut-homing IgA-secreting B cells by intestinal dendritic cells. Science (2006) 314:1157-60. doi:10.1126/science.1132742

169. Palladino MA, Johnson TA, Gupta R, Chapman JL, Ojha P. Members of the toll-like receptor family of innate immunity pattern-recognition receptors are abundant in the male rat reproductive tract. Biol Reprod (2007) 76:958-64. doi:10.1095/biolreprod.106.059410

170. Fraczek M, Kurpisz M. Inflammatory mediators exert toxic effects of oxidative stress on human spermatozoa. J Androl (2007) 28:325-33. doi:10.2164/jandrol. 106.001149

171. Fichorova RN, Cronin AO, Lien E, Anderson DJ, Ingalls RR. Response to Neisseria gonorrhoeae by cervicovaginal epithelial cells occurs in the absence of toll-like receptor 4-mediated signaling. J Immunol (2002) 168:2424-32. doi:10.4049/jimmunol.168.5.2424

172. Yenugu S, Hamil KG, Birse CE, Ruben SM, French FS, Hall SH. Antibacterial properties of the sperm-binding proteins and peptides of human epididymis 2 (HE2) family; salt sensitivity, structural dependence and their interaction with outer and cytoplasmic membranes of Escherichia coli. Biochem J (2003) 372:473-83. doi:10.1042/BJ20030225

173. Com E, Bourgeon F, Evrard B, Ganz T, Colleu D, Jegou B, et al. Expression of antimicrobial defensins in the male reproductive tract of rats, mice, and humans. Biol Reprod (2003) 68:95-104. doi:10.1095/biolreprod.102.005389

174. Fichorova RN, Desai PJ, Gibson FC III, Genco CA. Distinct proinflammatory host responses to Neisseria gonorrhoeae infection in immortalized human cervical and vaginal epithelial cells. Infect Immun (2001) 69:5840-8. doi:10.1128/IAI.69.9.5840-5848.2001

175. Agrawal T, Vats V, Salhan S, Mittal A. The mucosal immune response to Chlamydia trachomatis infection of the reproductive tract in women. J Reprod Immunol (2009) 83:173-8. doi:10.1016/j.jri.2009.07.013

176. Wallace PK, Yeaman GR, Johnson K, Collins JE, Guyre PM, Wira CR. MHC class II expression and antigen presentation by human endometrial cells. J Steroid Biochem Mol Biol (2001) 76:203-11. doi:10.1016/S0960-0760(00)00149-7

177. Al-Mously N, Eley A. Interaction of Chlamydia trachomatis serovar E with male genital tract epithelium results in secretion of proinflammatory cytokines. $J$ Med Microbiol (2007) 56:1025-32. doi:10.1099/jmm.0.47241-0

178. Dixit E, Kagan JC. Intracellular pathogen detection by RIG-I-like receptors. Adv Immunol (2013) 117:99-125. doi:10.1016/B978-0-12-410524-9.00004-9

179. Rahman AH, Eisenberg RA. The role of toll-like receptors in systemic lupus erythematosus. Springer Semin Immunopathol (2006) 28:131-43. doi:10.1007/ s00281-006-0034-3

Conflict of Interest Statement: The authors declare that the research was conducted in the absence of any commercial or financial relationships that could be construed as a potential conflict of interest.

Received: 17 March 2014; paper pending published: 01 April 2014; accepted: 29 July 2014; published online: 12 August 2014.

Citation: McClure $R$ and Massari $P$ (2014) TLR-dependent human mucosal epithelial cell responses to microbial pathogens. Front. Immunol. 5:386. doi: 10.3389/fimmu.2014.00386

This article was submitted to Microbial Immunology, a section of the journal Frontiers in Immunology.

Copyright (c) 2014 McClure and Massari. This is an open-access article distributed under the terms of the Creative Commons Attribution License (CC BY). The use, distribution or reproduction in other forums is permitted, provided the original author(s) or licensor are credited and that the original publication in this journal is cited, in accordance with accepted academic practice. No use, distribution or reproduction is permitted which does not comply with these terms. 